\begin{tabular}{|c|c|}
\hline $\begin{array}{l}\text { ARTICLES } \\
\text { ARTICULOS }\end{array}$ & JOURNALISTIC COVERAGE \\
\hline ARTÍCULOS & OF POLITICAL AND \\
\hline & FINANCIAL CRISES AND THE \\
\hline & "'ISSUE'” OF POLITICAL \\
\hline $\begin{aligned} \text { Copyright } \odot 2013 \\
\text { SBPjor } / \text { Associacăo }\end{aligned}$ & CORRUPTION \\
\hline $\begin{array}{l}\text { Brasileira de } \\
\text { Pesquisadores em } \\
\text { Jornalismo }\end{array}$ & $\begin{array}{l}\text { ISABEL FERIN CUNHA } \\
\text { Universidade de Coimbra }\end{array}$ \\
\hline
\end{tabular}

\begin{abstract}
This article analyzes the relationship between news coverage, political communication, crises and corruption, focusing on Western democracies and particularly Portugal. Firstly, political communication and news coverage are discussed, based on the assumption that the commoditisation of the goals of media and information companies has resulted in changes in the balance between the political and media fields. Within this perspective, attention is devoted to the consequences of these changes in Western democracies, taking into consideration not only certain aspects that tend to subvert underlying principles of representative democracy, but also the emergence of new social movements craving greater democratic participation in the public sphere. In addition, this study examines the concepts of crisis and political corruption, seeking to identify the historical and cultural elements that correlate the two phenomena in Western democracies, especially in Portugal. Finally, it addresses the processes of exposing corruption phenomena and their legal implications, as well as the principles of transparency of information and the consequences upon democracy.
\end{abstract}

KEYWORDS: News coverage. Media. Political communication. Western crisis. Political corruption.

\title{
COBERTURA JORNALÍSTICA DA CRISE POLÍTICA E FINANCEIRA E O “ISSUE" CORRUPÇÃO POLÍTICA
}

RESUMO - Nesta apresentação refletimos sobre as relações entre cobertura jornalística, comunicação política, crise e corrupção, tendo como foco as democracias ocidentais e, em particular, Portugal. Em primeiro lugar, disserta-se sobre comunicação política e cobertura jornalística, partindo do pressuposto de que a mercantilização dos objetivos das empresas mediáticas e da informação noticiosa alteraram as relações entre o campo da política e dos Media. Dentro dessa perspectiva, discute-se sobre as consequências dessas mudanças nas democracias ocidentais, levando em consideração alguns aspectos que tendem a subverter princípios inerentes à democracia representativa, mas também a eclosão de novos movimentos sociais que visam auma maior participação democrática no espaço público. Em seguida, discorre-se sobre os conceitos de crise e corrupção política, procurando identificar os elementos históricos e culturais que interrelacionam os dois fenômenos nas democracias ocidentais, sobretudo em Portugal. A título de conclusão, abordam-se os processos de desocultação dos fenómenos de corrupção e as implicações para o campo jurídico, bem como os princípios de transparência da informação e suas consequências na democracia.

Palavras-chave: Cobertura jornalística. Media. Comunicação política. Crise europeia. Corrupção política. 


\section{LA COBERTURA PERIODÍSTICA DE LA CRISIS POLÍTICA Y FINANCIERA Y LA CUESTIÓN DE LA CORRUPCIÓN POLITICA}

RESUMEN - En este trabajo se reflexiona sobre la relación entre cobertura de prensa, comunicación política, crisis y corrupción, centrándose en las democracias occidentales y, en particular, Portugal. En primer lugar, analizaremos la comunicación política y su cobertura informativa, a partir del supuesto de que la mercantilización de los objetivos corporativos de las empresas de información ha dado lugar a cambios en el balance entre el campo de la política y el de los medios de comunicación. Desde esta perspectiva se discuten las consecuencias de estos cambios en las democracias occidentales, teniendo en cuenta no solo algunos aspectos que tienden a subvertir los principios esenciales de la democracia representativa, sino también la aparición de nuevos movimientos sociales que buscan una mayor participación democrática en el espacio público. A continuación, nos centraremos en los conceptos de crisis y de corrupción política, para tratar de identificar los elementos históricos y culturales que establecen una correlación entre los dos fenómenos en las democracias occidentales, especialmente en Portugal. Para concluir, nos ocuparemos de los procesos de desenmascaramiento de fenómenos de corrupción y sus implicaciones jurídicas, así como de los principios de transparencia de la información y las consecuencias para la democracia.

Palabras clave: Cobertura informativa. Medios de comunicación. Comunicación política. Crisis europea. Corrupción política.

\section{PREAMBLE}

Coverage of political communication in Western democracies has undergone profound developments in recent decades due both to technological factors and changes in media, economic, political and social systems. One of the most decisive factors has been the increasing centrality of the media and the consequent need of the political system to adapt to this reality. Among the strategies adopted is the delivery of political communication management to political advisers, and other professionals like spin doctors who tend to administer the relationship between politicians (and governments) and citizens through a logic of "attracting and persuading audiences." This phenomenon determines the mobilization of all resources in order to weaken opponents; these include: rumors, allegations or suspicions of corruption. On the other hand, the pressure on media companies to make profits and increase their audiences tends towards the scheduling of certain political issues, such as corruption charges. Their potential to provoke shock leads to increased audiences (ALLERN; POLLACK, 2012, p. 9-28). If a crisis scenario is added to the equation, involving economic matters or democratic values, then the importance of reflecting upon all these factors together can be understood. 
In this light, the paper describes coverage in Western democracies, relating it to changes in political communication, and develops the coverage of political corruption within a crisis scenario.

\section{CONTEXTS OF NEWS COVERAGE AND POLITICAL COMMUNICATION}

The representation of political corruption by the media in Western democracies is intrinsically related to the characteristics of news coverage in political communication, which has a horizontal dimension consisting of the relationships between politicians and the media, as well as a vertical dimension involving political institutions as a whole, and politicians and their relationships with citizens (BLUMLER; GUREVITCH, 1995). This media triangle involves political players, businesses, media professionals and citizens, with the latter being regarded as audiences.

McNair (1999) outlines the flow of political communication and begins by listing the political organizations and political interests involved, such as parties, public organizations, governments and pressure groups. Following on from this, he refers to the area of the media, stressing that they act on the basis of economic affiliations and advertising agencies, depending on technological and human resources, as well as production routines and audience targets. The final element in the chain of political communication flow is the public, who are not only the recipients but also the weakest link, voting at elections as a means of responding. Meanwhile, the progressive replacement of the principle of mediation in political communication by the principle of mediatisation, has resulted in the penetration of values inherent to the media sphere in political life (MAZZOLENI; SCHULZ, 1999; MEYER, 2002; RUBIM, 2004; AVRITZER; FILGUEIRAS, 2011 ).

This process began in Europe in the 1980s, as a result of the development of new technologies and market liberalisation policies which gradually led to the commoditisation of journalistic information. This evolution has had consequences for the news coverage of political phenomena, and for political communication strategies, resulting in the so-called 'Americanisation' of politics, distinguished by the introduction of aspects arising from advertising and markets (BLUMLER; GUREVITCH, 1995; 2000). Patterson (2003, p. 22), referring to the evolution of American journalism over the latter decades of the $20^{\text {th }}$ century, notes that the number of 'serious' news items has decreased, while 'light' news has been on the increase. This has meant that news involving political coverage, political communication and relevant public policy issues, that 
is to say, serious news, has given way to other light news, which itself has tended towards sensationalism, and that furthermore was deemed to be out of context with regard to time and space. In addition, this has led to greater focus on matters centred on a particular character, unrelated to public policies.

The decrease in media appearance time (sound bites) has generated the belief in politicians and the politicized elite, that there is a progressive distortion in the quality of policy, which is further exacerbated by a declining ability on the part of politicians to reach the public at large. In response to this situation, policy-makers have focused on political marketing and aggressive strategies of political persuasion, in order to impose themselves in the media and reach the electorate more effectively. Moreover, since politicians' verbal messages are often truncated, shortened and framed by journalists, images of politicians tend to acquire greater significance (GRABE, 2009, p.54). With these assumptions and in order to reach the public and overcome the constraints identified in the media, especially on television, governments and parties usually choose leaders and candidates with greater personal potential in the media.

The process of political personalization is a political response to the difficulties that governments and political parties face when appealing to citizens and voters, but it is also a strategy that draws attention to the building of media personalities as celebrities. The public image of governments and candidates is always portrayed to include qualities such as trust, authority and security. However, the credibility of political actors also depends on what aspects of their private lives have become public, such as moral and physical appearance: oral proficiency (speaking well, using the right word at the right time); a fitting image (calm appearance, appropriate dress); credibility (keeping promises) and reputation (honesty, integrity and probity).

Within the context described, politics involves new players, who are preferably located backstage in governance and political campaigns (ALMEIDA, 2004; LOUW, 2005). These players are highly skilled professionals, such as those found in marketing companies, experts in public policy, political advisers (spin doctors), journalists and political commentators (pundits and opinion makers). These professionals are characterized by their expertise in technical and communication strategies, and the absence of any party affiliation or loyalty. The arrival of these experts into politics has led to the increased complexity of political relationships in Western democracies, and also the position of 
players in defining the political game.

On the other hand, the role that these actors assume in the daily life of party politics and governance has resulted in the proliferation of information "wars", focusing on the strategies of political advisers, in order to impose "favourable opinion" in the public sector (MAAREK, 2007). The struggle to establish the most favourable attitude of either a particular political agent, or issue, in both the political field and in public opinion, involves the ability to establish, throughout the media, political agendas imposing the notion of "how to think" (ALBUQUERQUE, 2004; MERAZ, 2011). Being visible in the media and getting the general public out of politics, leads to the use of multiple media (traditional and W.2) and multiple communication strategies, which include the use of corruption accusations that can undermine the legitimacy of potential opponents (JENSSEN; FLADMOE, 2012, p. 53-71)

The reporting of cases of alleged corruption and scandals in the media which give rise, without justification, to proving the culpability of the politicians involved, also contributes to discrediting democracy, as well as the political system itself and its agents. Simultaneously, the complaint or even the mere suggestion of such scenarios even existing has constituted one of the great weapons of political struggle: allowing the patrimony of a politician, within a highly personalized system, based on his/her image and reputation, to be eroded immediately. Thus, these types of complaints are one of the most common ways to neutralize opposition candidates and promote "the settling of scores" in the public arena. Moreover, such strategies feed the media industry by encouraging the production and consumption of news and giving more power and visibility to the media.

According to Allern and Pollack (2012, p. 9-28) media coverage of these issues is associated with increased competition between traditional and online media, the need to capture audiences, establish schedules and save resources, and also with promoting political transgressions in a sensationalistic way. It is also linked to the evergrowing divide between the demands of public codes of behaviour and the practices of individual politicians, as well as the strategies of political advisers to annihilate opponents and maintain control over political agendas.

The political field involves, therefore, complex processes of information management and communication, along with specific skills and competencies in managing human resources and technology. The strategic objective is to control agendas and impression management in 
the mainstream media, especially television, where politicians are more often exposed and forced to adopt a profile. As a complement, advisors and public relations staff, the people operating behind the scenes, have to monitor closely client image adjustment, drawing on the help of regular polls.

The aforementioned American and European trend went on to be echoed in Portugal, some decades later. This delay was due to various reasons, such as the late introduction of a media market and the consequent effects of this change on social practices and policies (SERRANO, 2006; FERIN CUNHA, 2007; JALALI, 2007). In Portugal, after a decade-long expansion of the media and advertising fields, the economic and financial crisis led to a market crunch. In response to this situation, the corporate groups who were running the printed media, television broadcasts and online media, sought to generate synergies, aiming at lowering production costs. Thus, major restructuring in newsrooms took place, with the goal of amalgamating news production centres. At the same time, human resources were optimised, with journalists and other professionals facing growing levels of job insecurity, while flexibility concerning working hours increased and a growing number of tasks were delegated to freelancers, daily workers and interns (GARCIA, 2010). The migration of advertising, which due to the economic crisis had already been reduced to subscription-based television channels and digital media, brought about further constraints to Portuguese journalism.

While economic and professional factors have limited the capabilities of news media in recent decades, resulting in 'inexpensive' and profit-centred journalism, like the News of the World, for instance, it is no less true that there remains a need to keep audiences involved in transforming the news into a show of their own. The news as entertainment and entertainment-information alone hardly poses any serious threat to democracy (McNAIR, 1999). In fact, this type of coverage, when associated with political speeches rooted in the principle of credibility, may even garner greater visibility for political communication, drawing a large section of the public, traditionally oblivious of public issues, encouraging participation in public debate and, therefore, in democracy (BRANTS, 1998). However, as Patterson noted (1994), a sensationalist and commercial approach to political information tends to boost populism, contributing to the politicisation of journalism and emphasising the backstage of politics.

On the one hand, this set of trends in news coverage results in the 'tabloidisation' (ESSER, 1999) of political communication 
and increasing alienation of ordinary citizens from the political field, while on the other hand, it encourages the emergence of a new audience standard, marked by fragmentation, volatility and an absence of any ideological affiliation seeking to address the lack of political information by resorting to alternative means (ATKINSON, 2009; CANAVILHAS, 2009). While the former audiences focus preferably on generalist broadcasters, the latter focus on online vehicles in their search for information that might differ from the ordinary menu offered by traditional media (NAPOLI, 2011). The intersection of the two latter trends with aggressive political communication strategies, involving elements of pop culture, has intensified distrust in representative democracy, demonstrated by growing alienation of citizens from electoral acts (WOLTON, 2008).

To those constraints, a common feature in most Western democratic societies, one must add specific aspects that pertain to Portuguese society. For instance, there is the traditional promiscuity between journalism's elite and politicians, and also between journalists and the judicial sector. This adds to a clear rotation among party members and sympathisers in carrying out their public duties and in occupying governmental seats, as well as holding executive positions in large economic groups, both in the public and private sectors (MORGADO; VEGAR, 2003; MORGADO, SILVA; 2008; COSTA, FAZENDA, HONÓRIO, ROSAS, LOUÇÃ, 2010; TRANSPARÊNCIA E INTEGRIDADE REPORT, 2011).

It is also necessary to emphasise the interest groups associated with media companies, who put party and political pressure on these companies, as well as the shortage of newsworthy raw material and its ability to generate audiences. The state, or specifically the government, has been seen to exert control over the private media through institutional advertising, as well as through criteria imposed by regulatory communication agencies. All these factors influence news coverage of the potential phenomena of corruption, in addition to aspects of the political arena, such as political marketing strategies by parties and members of government, competitive phenomena in the political market, politicians' images, perception of dominant and emerging values, and campaigns of disinformation and damage control (MAAREK, 1997; LEES-MARSHMENT, 2011).

\section{FRAMING CRISIS AND CORRUPTION}

Etymologically, the word originates from krisis, the Greek for separation, dispute, decision, verdict or final decision. Crisis in Latin 
means change, sudden imbalance; state of doubt and uncertainty; tension, conflict (CUNHA, 1982, p. 228). Bobbio, Matteuci and Pasquino, in his "Political Dictionary" (2004, p. 303-306), defines crisis as a moment of breach in a system, and considers that crises can be distinguished by three elements: unpredictability, limited duration, and impact on the functioning of the system.

To understand a crisis, it is necessary to take into account the internal and external contexts that predate it, as well as the changes in the system that have originated it. During the actual stage of crisis, one must devote special attention to questions of time and space, and the interested actors and protagonists. Bobbio, Matteuci and Pasquino consider that political and economic crises are inextricably linked, both at national and international level, as demonstrated by the international economic crisis of 1929-1932 that had severe repercussions on domestic political systems. Thus, crises can originate from inside or outside the system; they evolve according to a peak, which means that over the course of a crisis, other crises may overlap, causing overloads in political, economic, legal and social systems. For example, Europe is currently experiencing a financial crisis that has entailed several internal crises and peaks, which have resulted in ups and downs in stock markets, in credit rating scares and in the measures adopted by EU member states.

In addition, Bobbio, Matteuci and Pasquino distinguish system crises from government and international crises. A system crisis is associated with change of political regime, as well as changes in legal and constitutional mechanisms and devices, for instance the end of a monarchy and the establishment of a republic, or at the end of a dictatorial regime and the introduction of democracy. System crises also involve transformations of socio-economic relations - including elements such as production relations, distribution of wealth and income, and the notion of family (BOBBIO; MATTEUCI, PASQUINO, 2004, p. 304). It should be noted that the two aspects are deeply interlinked, which means it is impossible for any change in regime not to bring about changes in socioeconomic relations, or for socio-economic changes to occur without a substantial change in the philosophy and design of a regime (AVRITZER et al., 2008). Government crises are related to the operation of the government subsystem and may originate from internal factors inherent to the context and governmental structure, or external factors pertaining to relations with society or with situations resulting from unfavourable international environments. The author points out that one of the decisive factors of any government crisis may result from the relations 
between the politicians' class and society, and may depend on "the lack of representativeness of the political class in power".

The institutionalisation of procedures with a view to solving government crises aims primarily to control the damage that could affect the regime (BOBBIO; MATTEUCI, PASQUINO, 2004, p. 305). This reflection, applied to the current situation in many European countries, has led to urgent discussions on citizenship and the very future of representative democracy.

International crises arise from conflicts between countries. Historically, the concept has always been associated with conflicts, wars and the hegemonic ambitions of certain countries. According to Bobbio, Matteuci, Pasquino (2004, p. 305), there is a huge advantage in analysing international crises from the point of view of the available information, the quality and number of actors involved, the decision-making processes and the results achieved.

An exercise that could be useful for the current situation in Europe is an analysis of journalistic coverage of the financial crisis. In undertaking this exercise, one quickly identifies a small number of customised, active players, a profuse circulation of data and statistics, as well as few actual measures that could lead to a solution for the problem. Within this context, journalistic coverage by the media adopts the power of speech of interest groups represented inside the state, which through economic, financial and legal devices, encourages citizens to conform to vague interests, mostly financial in nature, of national and global scope (NASH, 2005). This process can be described to a large extent as the management of voices that reach the public arena and to which the media lends the floor, for example: the collective players, 'markets', 'banks', 'financial markets', 'the rich', G20, G8, or even the singling out of certain countries of particular geostrategic interest. Citizens are merely viewed as passive and reactive players, and identified as 'employees', 'contributors', 'civil servants', 'the retired', 'users of public services'. The voice of the trade unions and union federations is also passive or reactive in relation to the decisions made by the active players, as well as the 'demonstrators', 'rioters' or the 'outraged'.

The representation deficit in the public sphere, as sensed by the majority of citizens in various regions of the globe, and a growing suspicion toward the informative menu administered by media companies, have given rise to social movements with diverse goals. Examples of such movements include: the anti-dictatorship movements that exploded across North African countries; the movement of 'the 
outraged' against the austerity measures aimed at tackling the financial crisis in Europe, or even the 'Occupy Wall Street' movement in the United States, which is opposed to the practices of financial systems. All these movements have in common the use of online tools and social networks, as well as a specific strategy to change the dominant discourse of the public space, demanding new criteria of 'truth' and 'credibility' (ATKINSON, 2009).

For Raboy and Dagenais (1992, p. 2-5), crises are of great interest to the media, not only because they provide an opportunity to challenge the political system, the opponent or powerful partner, but also due to the economic advantages that such situations can bring to companies, as they generally generate an increase in available raw material for news-making and a growing demand from citizens/consumers. These same authors also consider that the media's tendency to fabricate or emphasise crises is traceable, and that they include procedures, which tend to be consistent with powerful interests and actors. Underlying this statement is the conclusion (KEANE, 1992, p. 20-21) that Western democracies have created a system of dangerous relations between the political class, businesses, media and journalists, allowing less than clear situations to occur.

These observations suggest that boundaries between the state and the interests of certain powerful groups have become increasingly blurred, as certain unscrutinised powers have emerged, bringing influence and various forms of corruption which mine the system from within. On the other hand, and at the same time, democratic political systems, when faced with crisis situations, tend to adopt safety measures that include the introduction of restrictions on media activities, and control over news sources and agendas. One example is the measures adopted by the mayor of New York on the accreditation of journalists dispatched to cover the 'Occupy Wall Street' protests, which tended to limit freedom of information.

The crisis is also a type of discourse on public affairs in the public arena, involving specific codes, where the focus is on certain types of narrative, sources, actors and opinion- makers. The crisis discourse resorts to persuasion and intimidation devices centred upon a coherent set of meanings, seeking to reflect the interests and ideological choices of very specific sectors of society. Under these circumstances the conventional media have played the role of amplifying elite voices and choices, conditioning the public areas of debate through the participation of opinion-makers and political leaders affiliated with 
the dominant system (COULDRY, 2010). During the financial crisis that began in 2007, with the collapse of Lehman Brothers, and in the years that followed, voices on the public stage sponsored a veritable "pensée unique", centred on the conformed and conformist vision of the causes of the financial crisis. Since then, the Western media have encouraged journalistic coverage of the financial crisis solely tending toward the exaltation of the interests of capital, as formed within the 'markets', and the punishment of the economy and workforce.

Moreover, crises cause an escalation of social demands, which in turn lead political and economic actors and agents to limit political and civil rights, notably through control over information. This control is conducted by overlooking transient micro and macropolitical aspects of the crisis, through processes of ideological guidance of speech regarding the economic and financial situation, added to simultaneous strategies of concealment, and manipulating information in the public domain. Regarding the current financial crisis, it is of the utmost importance to analyse how focused journalistic coverage is on global financial interests, hiding the economic and social consequences of the 'austerity measures', for instance, imposed in many countries of Southern Europe.

The 'spectacularisation' devices and 'hyper- mediaexploitation' of events and actors, are discursive development strategies of the political, economic and financial crisis (BRUCK, 1992, p. 109-110). Some of the most frequent discursive strategies are: the exhaustive and controlled presentation of information fragments contained in sound bytes; resorting to scenarios such as conferences or summits; customising public and institutional contexts; the denial of macrocontexts and direct culprits; control over opinions and voices with access to the public stage and the preference for moralistic frameworks. These criteria, incorporated into journalistic coverage by the press and television news programmes, limit the public's understanding of the crisis, render understanding of macro-contexts and alternative solutions more difficult, bring about breaches in social cohesion, solidarity among citizens and countries, as well as the strengthening of moralistic speeches with xenophobic tendencies.

In the Portuguese media, references to the crisis have been constant since the beginning of the millennium. Empirical studies on the coverage of the final stages in Prime Ministers' terms (Cavaco Silva, 1994-1995; António Guterres, 2001-2002; Santana Lopes, 20042005) by the recognised press, note the recurring frequency of topics 
such as deficit, economy, crisis and corruption (FERIN CUNHA, 2007, p. 30-38). In a subsequent empirical study of the 2009 legislative elections, the concern for issues pertaining to 'the crisis' and 'corruption' was once again confirmed (FERIN CUNHA, 2012). Thus, by analysing the press, one can conclude that the second most focused upon theme was 'economy, finance and crisis' (19.9\%, 208 out of 1043), and the fourth most was 'scandals and lawsuits' (5.4\%, 56 out of 1043). Meanwhile, on subscription-based television channels, out of a total number of 630 records, the themes 'scandals and lawsuits' (9.7\%, 61 mentions) and 'economy, finance and crisis' (4.9\%, 31 mentions) hold, respectively, the third and fourth highest placed mentions, within the context of the coverage of elections.

\section{POLITICAL CORRUPTION}

Rose-Ackerman (1999), discussing crisis and corruption, concluded that crises generate political, economic, social and moral changes. Firstly, the phenomenon results in the alienation of citizens from their rulers and tends to generate de-politicisation in the public sphere, paving the way for diminished perceived legitimacy of the political system and institutions. Secondly, in contemporary history, crises display mainly economic and financial characteristics that involve defrauding the expectations of citizens and societies, and clearly contribute to the increase in corruption phenomena, in their many forms.

Dobel (1978) considers that corruption results primarily from the sparse amount of goods available at a given time in a given society, which tends to bring out a sense of 'struggle for survival', coupled with a lowering in civic and ethical standards. For this author, political corruption is a phenomenon historically inherent to crisis contexts and to the final breaths of regimes, and is always associated, in the West, to legitimacy crises, where actors (citizens and politicians) qualify the political order as corrupt and undertake actions to overthrow it.

Gambetta (2002) argues that, in common language, corruption carries several notions, of which three are the most important. According to one idea, corruption pertains to the degradation of the (public or private) agents' sense of ethics, implying a lack of moral integrity and consequent depravation. From another perspective, corruption can be associated with a set of social practices stemming from the degradation of some institutions (public or private), its focus therefore lying on institutional relations and the organization of society. 
A third view of corruption highlights certain social practices, with strong cultural overtones, such as gifts, etc., in order to encourage or reward certain decisions from public or private agents.

The broadest definition of corruption refers to the misappropriation of assets or gains, while further elaboration on the concept leads to three main scenarios: a first, where the degradation of the involved parties' sense of ethics occurs; a second, with a set of predatory social practices within certain institutions; and the third scenario, where institutions and agents agree on misappropriation of benefits (HEIDENHEIMER; JOHNSTON, 2002, p. 3-73). The wrongdoings classified as corruption are diverse in nature, including 'gifts', 'gloves', 'backhanders', clientele relations, kleptocracy, nepotism, misappropriation of benefits, white collar crime, and organised crime.

Social perception of corruption involves elements of local and national culture, as the notion of what is legitimate and legal differs depending on the era and country. For example, in some countries, donations to parties are completely unlawful, but not in others and, under certain circumstances, are actually acceptable: "In Italy the socialists argued that the bribes they took were for their party rather than for personal gain, and that, since there is no other way for them to finance their electoral campaigns, donations should be legalized "(GAMBETTA, 2002, p. 34).

To elaborate further, political corruption can be defined as an abuse of power for one's own benefit undertaken by democratically elected political agents. This may occur while carrying out public duties, or afterwards, when politicians use the relative capital acquired during their terms in office to obtain undue gains. Wrongdoings occur mainly in four typical situations: during the running for political office; in the exercise of public office; while legislating or ruling, and after stepping down from political positions while still in charge of certain political duties in one's party (HEIDENHEIMER; JOHNSTON, 2002).

Political corruption is a crossroads between politics (power), the economy (companies and businesses), justice (the legal framework) and the media (the disclosure of information) (BLANKENBURG, 2002). La Porta and Meny (1997), Blankenburg (2002), Philp (2002), and Bobbio, Matteuci and Pasquino (2004), consider that privatisation in Europe throughout the 1980s and 1990s has contributed to an increase in corruption. They underline, firstly, that the financial and economic paradigm shift favoured certain already well-established interest groups, who have enjoyed increased privileges. Those groups have devised 
strategies, such as alternating managers between public and privatesector positions, in order to exert influence on governmental decisions.

La Porta and Meny (1997) have demonstrated that, from the late 1990s onward, there have been increasing indications suggesting a rise in corrupt practices in Western democracies, to such an extent that a phenomenon which was previously deemed sporadic by the public came to be regarded as truly endemic. The increased perception of (mostly political) corruption in Western societies and most notably in Southern European countries, such as Spain, Portugal and Greece, is linked to political changes initiated throughout the 1990s, with the accession of those countries to the EEC. Political change, the financial and economic expansion and growth of consumer society, resulted in the emergence of a new ruling elite. This group, mostly of rural origin and a notable newcomer to politics, combined traditional political practices such as cronyism and nepotism, with capitalist and consumer society values, adopting power strategies rooted in economic and financial interests. The most frequent types of political corruption thus arise in the forms of fraud, bribery, cronyism, misappropriation of gains, trafficking of influences, arbitrary favouring and illegal funding of political parties.

In Portugal, the disclosures of political corruption phenomena started in the 1990s and as some studies have shown (PAIXÃO, 2010), it was associated with the emergence of a media market, supported by private television operators and new ways of practising journalism. However, the phenomena of political corruption rose to particular prominence during the $17^{\text {th }}$ (March 12, 2005 to October 26, 2009) and $18^{\text {th }}$ (October 26, 2009 to June 21, 2011) constitutional governments, led by the Socialist Party under the leadership of Prime Minister José Sócrates. During this period, between 2006 and 2009, Portugal dropped from $26^{\text {th }}$ to $35^{\text {th }}$ place in the international ranking on public perception of corruption, conducted by Transparency International.

\section{DISCLOSURE AND TRANSPARENCY: AN INCONCLUSIVE CONCLUSION}

Amidst an adverse situation in Western democracies, where the ordinary citizen tends to view politics as some sort of agency aimed at administrating the interests of capital and finance, speeches on disclosure and transparency have gained an increasingly symbolic value (AVRITZER et al., 2008). Both processes rely on common devices, such as scenarios, roles and legal discourses, regardless of the actions that take place in public arenas covered by the media. The goal of these procedures 
is to establish the 'truth', identify the 'lie' and punish the 'guilty'. The interests of the media, journalists and judges converge, as they all face a political system of hidden powers and fight against certain fiercely established interests within the state. The former, in contexts of economic and financial crisis, can make profits from presenting corruption as a raw material, as well as from the subsequent 'judicialisation' of politics. In turn, justice may regard the media and journalists as potential allies, capable of overcoming the slow paced mechanisms of legal bureaucracy and disarming pressures from within the political arena.

However, while judges appear, in the eyes of ordinary people, as punishers, whose actions are hindered by obligations and codes, journalists apparently seem to enjoy greater freedom, guided by a representation of justice that transcends the boundaries of the institution. This public perception of justice allows the media to assume the role of intermediary between powers, as an accuser, defence lawyer, or judge, in cases where news potential is greatest. In these cases, violations of confidentiality during investigations are also frequent, as they are often promoted by the media, reporting on information obtained from judicial sources, creating partial knowledge of the facts, usually referred to as "hypothetical information", and encouraging trials by the public.

Thus, the media become a permanent stage for speeches disclosing corruption, where the 'truth' is established and constantly re-established through moral discourses and legal arguments. In this context, political marketing and political communication play a crucial role in the design and survey of scenarios, in creating strategies for political agents and in exerting control over discourses about the 'truth'. Resorting to disclosure and denunciation not only affects political actors, by delegitimizing their actions, but also promotes discredit and distrust in representative democracy as a whole.

While disclosure processes follow their courses, calls for government transparency arise in order to strengthen confidence in democracy. Lindstedt and Naurin (2010) contend that merely making information accessible or enacting legislation on corruption, are not enough. They consider that measures adopted by governments and public officials aiming to make institutions more transparent are actually less likely to apply to, or tackle successfully, the problem than initiatives which are embraced by the public. Generalised distrust in measures adopted by governments/states is rooted in the perception that there are two types of transparency: the one controlled by the information producer (the actor who produces the information and accepts responsibility for 
its publication); and the other, which is not controlled by the producing agent, meaning that the information is published by parties other than those who produce it, with no involvement in the process. The first form of transparency is more likely to prove ineffective, resulting merely in formal transparency procedures.

These statements serve the purpose of highlighting the decisive role of the public in the fight against corruption, in particular through awareness of the damage caused to representative democracy and the economy. In order for transparency to serve as an actual means of preventing political corruption, it is necessary to make information available to citizens, alerting them to the scale of the crimes as well as to the alleged offenders, thus inhibiting their criminal conduct. However, in order for institutions to be more transparent and broader levels of participation to be reached, and for civic responsibility to be enhanced, radical change in the notion of democracy and democratic participation is required.

A more advanced level of participatory democracy is therefore necessary, one that might bring together new actors and forms of political communication, using the media and alternative political contents, and which could break the domination of Western representative democracies safeguarding obscure interests lodged within their very cores.

\section{REFERENCES}

ALBUQUERQUE, Afonso de. Propaganda Política e Eleitoral. In: RUBIM, Antonio Albino Canelas (org.). Comunicação e Política. Salvador: Edufba, 2004. p. 451-482.

ALLERN, Sigurd.: POLLACK Ester. The mediated construction of Political Scandals in Four Nordic Countries. Goteborg: Nordicom, University of Gothenburg, 2012.

ALMEIDA, Jorge. O Marketing Político-eleitoral. In: RUBIM, Antonio Albino Canelas (Org.). Comunicação e Política. Salvador: Edufba, 2004. p. 31 0-346.

ATKINSON, Joshua D. Alternative Media and Politics of Resisteance: a communication perspective. New York: Peter Lang, 2009.

AVRITZER, Leonardo; FILGUEIRAS, Fernando (Org.). Corrupção e Sistema Político no Brasil. Rio de Janeiro: Civilização Brasileira, 2011.

AVRITZER, Leonardo; BIGNOTTO, Newton; GUIMARÃES, Juarez; STARLING, Heloisa Maria M. (org.). Corrupção: Ensaios e críticas. Belo Horizonte: Editora UFMG, 2008. 
BLANKENBURG, Erhard. From political clientelism to outright corruption The rise of the scandal industry. In: KOTKIN, Stephen; SAJÓ, Andras. Political corruption in transition: A skeptic's handbook. Budapest: Central European University Press, 2002. p. 149-165.

BLUMLER, Jay; GUREVITCH, Michael. The Crisis of Public Communication. London: Routledge, 1995

BLUMER, Jay; GUREVITCH, Michael. Rethinking the Study of political Communication. In:

CURRAN, James; GUREVITCH, Michael. Mass Media and Society, 3th edition, London: Arnold, 2000.

BOBBIO, Norberto; MATTEUCI, Nicola; PASQUINO, Giamfranco. Dicionário de política. Brasília: Universidade de Brasília, 2004.

BRANTS, Kees. Who's Afraid of Infotainment? European Journal of Communication 13 (3), 315-335.1998

BRUCK, Peter .Crisis as Spectacle: Tabloid News and Politics of Outrage. In RABOY, Marc; DAGENAIS, Bernard. Media, Crisis and Democracy. London: Sage: 108-119. 1992

CANAVILHAS, João. A Comunicação Política na Era da Internet. 2009: Covilhã: Labcom

COSTA, Jorge; FAZENDA, Luís; HONÓRIO, Cecília; ROSAS, Fernando; LOUÇÃ, Francisco. Os donos de Portugal. Porto: Afrontamento. 2010.

COULDRY, Nick. Why voices matters: Culture and politics after neoliberalism. London: Sage, 2010.

CUNHA, Antônio Geraldo da. Dicionário etimológico da língua portuguesa. São Paulo: Nova Fronteira, 1982.

DELLA PORTA, Donatella; MENY, Yves. Democracy and corruption in Europe. London: Observatoire du Changement en Europe Occidental, 1997.

DOBEL, J. Patrick. The corruption of the state. Los Angeles. American Political Science Review. v. 72, n. 3. New York, 1978. p. 958-973.

ESSER, Frank. Tabloidization of the News: A comparative Analysis of Anglo-American and German Press Journalism. European Journal of Communication, 14: 3: 291-324, 1999

FERIN CUNHA, Isabel (Coord.) Jornalismo e democracia. Lisboa: Paulus, 2007.

FERIN CUNHA, Isabel. A cobertura televisiva de partidos, candidatos e temas nas legislativas. In: FIGUEIRAS, Rita. Os Media e as eleições: Europeias, legislativas e autárquicas. Lisboa: Universidade Católica Editora, 2012. p. 95131.

GAMBETTA, Diego .Corruption: An analytical map. In: KOTKIN, Stephen, SAJÓ, Andras. Political corruption in transition: a skeptic's handbook. Budapest: Central European University Press, 2002. p. 33-56.

GARCIA, José Luís. Para o estado da arte da investigação sobre os jornalistas portugueses. Revista Media \& Jornalismo. v. 9, n. 2. Lisboa, 2010. p. 125150. 
GRABE, Doris. Mass Media and American Politics. Washington: CQPress, HEIDENHEIMER, Arnold J.; JOHNSTON, Michael (Ed.). Political corruption: Concepts \& contexts. (3. ed.). New Jersey: The State University. 2002

JALALI, Carlos . Partidos e democracia em Portugal. Lisboa: ICS, 2007.

JENSSEN, Anders Todal; FLADMOE, Audun. Ten Commandments for the scandalization of political opponents. In: ALLERN, Sigurd; POLLACK, Ester (Eds.) Scandalous! : The mediated construction of political scandals in four Nordic countries. Gothenbourg: University of Gothenburg, 2012. p. 53-71.

KEANE, John. La vida pública y el capitalismo tardio: Hacia uma teoria socialista de la democracia. México: Alianza, 1992.LEES-MARSHMENT, Jennifer. Political marketing: Principles and applications. Park Square: Routledge, 2011

LINDSTEDT, Catharina; NAURIN, Daniel. Transparency is not enough: Making transparency effective in reducing corruption. International Political Science Review. v. 31, n.3, London, 2009. p. 301-322.

LOUW, Eric. The Media and Political Process. London : Sage 2005

MAAREK, Philippe J. Communication \& marketing de I' homme politique. Paris: LexisNexis Litec, 2007.

MCNAIR, Brain. An Introduction to Political Communication. London Routledge, 1999

MAZZOLENI, Giampietro ; , SCHULZ, Winfried. « Medialization » of Politics : A Challange for Democracy? Political Communication, 16(3), 247-262,1999

MERAZ, Sharon. The fight for "how to think": Traditional media, social networks, and issue interpretation. Journalism. v. 12, n. 1. New York, 2011. p. 107-127.

MEYER, Thomas. Media democracy: How the media colonize politics. Cambridge: Polity Press, 2002.

MORGADO, Diogo; SILVA, Patrícia. Recompensas dos altos cargos: Portugal uma pesrpectiva comparada. IV Congresso da Associação Portuguesa de Ciência Política. 2008

MORGADO, Maria José; VEGAR, José. Fraude e corrupção em Portugal: O inimigo sem rosto. Lisboa: Publicações D. Quixote,. 2003.

NAPOLI, Philipe M. Audiences Evolution: New Ttechnologies and the Transformation of Media Audiences. New York: Columbia University Press. 2011

NASH, Kate. Contemporary Political Sociology: Globalization, Politics, and Power. Oxford: Blackwell Publishing 2005

PAIXÃO, Bruno. O Escândalo político em Portugal. Coimbra: Minerva, 2010.

PATTERSON, Thomas E. Out of Order. Nova York: FirstVintage, 1994

PATTERSON, Thomas E. Tendências do Jornalismo Contemporâneo: Estarão as notíciasleves e o jornalismo crítico a enfraquecer a Democracia? Lisboa. Revista Media \& Jornalismo, 2, :CIMJ, pp. 19-47, 2003.

PHILP, Mark. Political corruption, democratization, and reform. In: KOTKIN, Stephen; SAJÓ, Andras. Political Corruption in transition: A skeptic's handbook. Budapest: Central European University Press, 2002. 
RABOY, Marc; DAGENAIS, Bernard. Media, crisis and democracy. London: Sage. 1992.

ROSE-ACKERMAN, Susan. Political Corruption and Democracy. Faculty Scholarships Series Paper 592.1999.

RUBIM, António Albino Canelas. Espetacularização e Midiatização da Política. In: _-__-_ (Org.). Comunicação e Política. Salvador: Edufba, 2004. p. 181 221.

SERRANO, Estrela. Jornalismo político em Portugal: a cobertura de eleições presidenciais na imprensa e na televisão (1976-2001). Lisboa: Ed. Colibri, 2006.

TRANSPARÊNCIA E INTEGRIDADE REPORT. Sistema nacional de integridade. Lisboa: Transparência Internacional/ICS, 2011.

WOLTON, Dominique. La communication politique: construction d'un modèle In : La Communication Politique. Paris : CNRS, 2008.

Isabel Ferin Cunha Associate Professor in the School of Arts at the University of Coimbra. Department of Philosophy, Communication and Information. Senior researcher at the Media and Journalism Research Centre. E-mail: barone.ferin@gmail.com 
JOURNALISTIC COVERAGE OF POLITICAL AND FINANCIAL CRISES 